\title{
THE LAST JUDGMENT AS REPRESENTED IN THE SISTINE CHAPEL BY MICHELAGELO AND IN THE ROMANIAN BYZANTINE VORONET
}

\author{
Giugea Gheorghiţa Daniela
}

Phd, University of Pitesti, Romania, giugeafloriceldaniela@yahoo.com

\begin{abstract}
The Last Judgment is one of the most common themes in both Byzantine iconography and in the Western one, being met in: the nave, the narthex, the exonartex or on the exterior, on the wall facing the sunrise or sunset. In our country, where the Byzantine model is respected, the most significant scene was painted on the western façade of the Voronet church of Moldavia in 1547 by a painter called Marcu. Shortly before, namely in 1541, a different Last Judgment had been completed in a different way, by the great Renaissance artist Michelangelo on the altar wall of the Sistine Chapel.It is, perhaps, the most famous representation of this scene in Western art. This article aims to present the two works created during the same period but in two different ways, each with its elements of originality. Considered a masterpiece of Romanian medieval art, the Voronet scene enrols in a special program as compared to other representations from our country or from other areas with Byzantine tradition, contributing to the formation of a specific Moldavian style. Apart from the religious significance, which underlies its development, specialists in the field concluded that there is here a political influence. One may add the high craftsmanship which gave value and durability to the composition. Michelangelo's Judgment was executed by order of Pope Paul III. It breaks out from the patterns before, being considered an extraordinary work both in regard to the arrangement of figures and from the compositional point of view. The painter uses here bold foreshortenings, conferring dramatic load on the scene, at the same time demonstrating a sound knowledge of the anatomy of the human body.
\end{abstract}

Keywords: Last Judgment, Voronet, Sistine Chapel, Byzantine art, Western art, originality.

\section{INTRODUCTION}

\subsection{Byzantine Art}

Located in the close proximity of the Byzantine Empire, the Romanian Countries were placed under the strong influence of Byzantine art that dominated the Christian East between the $\mathrm{IV}^{\text {th }}$ and the $\mathrm{XV}^{\text {th }}$ century and contributed to the formation and the development of the Romanian medieval art. In Wallachia, there stands distinctive the Princely Church of Curtea de Arges, one of the oldest monuments modelled after the Chora Church, a creation of Paleologic art in Constantinople. In Moldova, in the sixteenth century there emerged Byzantine elements along with local trends, famous painting assemblies that decorate the places of worship in the area. To them were added valuable artistic creations that, in subsequent centuries, enriched the Christian art produced throughout the Romanian territories. 
Byzantine art was created from: paleo-Christian, Oriental, Hellenistic and Roman elements that determined, through the adding of the spiritual content, the formation of an art deeply subordinated tothe religious feeling. At the same time, it was the main means by which the king imposed his authority over other nations through the pomp and ceremony of the court, while the artist occupied a secondary role as a mere executor of the will of divinity (Lazarev, 1980, pp. 51-65). Byzantine iconography was very strict, subject to certain standards. Although it was despised at some point in Western Europe, it would later become highly appreciated (Cavarnos, 2005, pp. 15-16). Among the features of the Byzantine art, one may include: frontality, thus establishing a direct relationship with the viewer; the integral or at least three-quarter rendition of the image of the saints; the existence of the halo around the heads of Christ, of Virgin Mary, of Saint John the Baptist, of all the saints and holy angels; in rendering the attire, one does not seek naturalness, the folds do not follo wthe shape of the body, using geometric shapes that confer spiritual character and do not send the viewer to the natural world, but rather to the kingdom of God; avoiding naturalism in regard to the representation of hands and feet: thin, long fingers; the eyes are rendered as being very large, suggesting the inner human being, the long and narrow nose symbolizes spirituality; the use of the golden background, and the objects are represented schematically, but also from a reverse perspective and from a psychological one. From the aesthetic point of view, the following elements are resorted to: simplicity, symmetry, balance, grace, clarity, measure (Cavarnos, pp. 14-27).

\subsection{Western Art: Renaissance}

Western art had a different development from that of the Byzantine art. The Renaissance made its appearance in Italy, where its progress was hampered by a period of dominance of the Germanic peoples. From here it spread across Europe influencing the subsequent artistic development. Unlike Byzantine art, Renaissance placed at the heart of its concerns the human being, through Humanism. Given that, in the medieval theological culture, the human being was subjected to religious dogma, being considered a sinful being and one that had to move away from the pleasures of life, through rebirth of humanism it now became important. Therefore, the influence of antiquity brought to the fore the interest towards the person, towards real life, but also towards ancient creations (Suter, 1967, pp. 187-188). If in Byzantium everything was controlled through the centralized state, and art was subject to religious rules, in the West it was a quite varied manifestation. Although here there were Byzantine artists who decorated numerous places of worship with specific artistic works, Italian artists gradually began to break away from the Byzantine tradition and create something different. The first to break away from this influence was Giotto, then gradually, it led to artistic expressions that were totally different from Eastern art. He introduces contemplation of nature that did not exist in Byzantine art, being very close to reality. In the sixteenth century Italian Renaissance reached its climax. It was now that the Last Judgment by Michelangelo Buonarroti was created, at the command of Pope Paul III.

\section{METHODOLOGY}

\subsection{The Last Judgment in Byzantine Erminia}

In his Erminia made after the model provided by Athos, Dionysius of Fourna explains how the scene of Judgment was represented. Thus, it begins with the figure of Christ, rendered on a high chair, wearing white robes, "with His right hand He blesses the saints, and with the left hand He shows to the sinners the signs of the nails" (Dionysius, 2000, p. 215). He then mentions the presence of light around Him, then the angelic cohorts and the words that are reproduced above: Jesus Christ, the Righteous Judge. Next, on each side, there are Virgin Mary and John the Baptist praying for forgiveness for people's sins. Under the feet of Christ, Dionysius mentions the existence of the tribunal, where there are: the sign of the cross, "the seat of the Lord and [all] the testimony of the Law and the prophets" (Dionysius, p. 215), the Gospel, then the dove, the symbol of the Holy Spirit, the crown of thorns, the spear, the sponge, the nails, the mantle" (Dionysius, p. 215). On each side of the seat there are two angels and Adam and Eve on their knees looking at Christ. Then, to the Saviour's left and right side, the prophets Daniel, Malachi and Judith appear represented with papers in their hands. Also on each side of Christ's there are the twelve apostles rendered in white. Joining them, on the right, there are hosts of saints bearing good deeds. In the register from the right of Christ is represented heaven, "built with crystal, gold and precious stones in all directions, and graced with great and beautifully decorated trees, and flying birds of many kinds" (Dionysius, p. 216). At the gate of heaven St. Peter with a key in his hand, Archdeacon Stephen and all cohorts of angels around them want to enter heaven. In the midst of Heaven, there appears Virgin Mary on a golden stall surrounded by two angels. To her right is rendered the thief Dismas with a cross in his hand. On the other side of Virgin Mary there are the five wise virgins with veiled heads. Outside of heaven there appear five foolish virgins "with sad countenance and crying, with all the candles burnt out, and bent down"(Dionysius, p. 216). In heaven, under Virgin Mary there is old Abraham, white-haired, sitting on the stall and holding on his knees the soul of 
Lazarus, in a white shirt. Isaac appears to his right, and to his left Jacob, both being rendered as elders sitting on chairs turned slightly to Abraham. Under their feet, four rivers are flowing from heaven: Pishon, Gihon, Tigris and Euphrates. In the midst of heaven there appears the Tree of Life with the image of Christ in it, represented as a beautiful tree full of fruit. Behind the foolish virgins is reproduced Lazarus' repose and an angel that is taking his soul. To Christ's left, the scene is completed by "eternal fire", by Michael the Archangel with the trumpet and then by the sinful, "some of whom are shed by the sea, and others are coming out of the graves: men, women, and children of all ages" (Dionysius, p. 217). There follows the prophet Moses, accompanied by a group of Jews whom he reprimanded for having crucified Christ, now their judge. Anna and Caiaphas are also present, as well as an angel that holds the sky in his hand, rolling it, and Isaiah. From beneath Christ's feets prings the river of fire that flows till the lower right corner from the south, where the all-eating dragon is represented. In the river of fire appear all the sinners that Dionysius lists in his Erminia (See Dionysius, p. 217). Arie is represented with his head down in the mouth of the dragon and on his head appears Beelzebub, "the master of the demons, with the soul of Judas, holding it with a claw in his arms, and in the other he holds a glass, with fire coming out of it" (Dionisie, p. 217). The fire angels are represented to torment sinners and demons. Under the river of fireis rendered the Antichrist, with a king's crown and two snakes around his neck, wearing an imperial coat and held by the hands by two devils, one with a club and another whipping his back. It also mentions the scales of justice, which appears held by a hand emerging from a cloud. Inits centre, a naked soul with its hands tied behind its back. On both their sides appear a veil and a millstone; two devils, one with three millstones on his back and the other pulling a plate with a hook. An angel thrusts a spear in the belly of the devil. The scene ends with the representation from the bottom, namely that of the death of the Rich Fool, surrounded by family and wealth and with demonsthat pull his soul with a hook (Dionysius, p. 218). To this one may add the plurality of messages accompanying the representation of some of the characters that make up the scene.

\subsection{The Evolution of the Scenes of the Last Judgment in the Romanian Space}

In our country the oldest representation of the Last Judgment, as mentioned by ID Stefanescu, appears in Transylvania, at Streiu, in the nave of the church. Although the painting is in ruins, there is a light Italian influence from the XIIlth or XIVth centuries (Stefanescu, 1973, p. 158). Other churches in Transylvania where this scene appears painted are Santa Mărie Orlea, with Byzantine and Italian influences, and Streisângeorgiu of Hunedoara. (Florea, 2007 p. 70) In the first church, the Last Judgment is also represented in the nave, just as in the case of Streiu (Stefanescu, p. 158). At Criscior church in Hunedoara, the scene is painted on the north wall, at the exterior of the abode (Drăguţ, Dictionary, 1976 p. 114). To render the original sin, personification is used, that of a naked woman with a snake around her (Stefanescu, $p$. 158). Therefore, in Transylvania one may observe both the different arrangement of the scene and the Byzantine and Western influences.

In Wallachia, the Last Judgment began to be widely represented only in the XVIlth century, before that moment there being no valuable paintings. Fragments lacking in special importance were kept at the Royal Church of Arges. To these one may add those of Stanesti. In point of positioning, to the south of the Carpathians, the scene was found before the century mentioned: in the narthex, on the eastern wall or at the exterior, on the western one.

The scene occurs from early Christianity, in the catacombs and on sarcophagi, being represented by Crist separating the good from the bad. To this there were added elements introduced by Byzantine iconography (Stefanescu, p. 159). Starting with the twelfth century, it could be found in the churches of:Torcello, Kazandjilar-Djami of Thessaloniki at Mistra in Bulgaria at Bačcovo, at Athos, Lavra etc. (See Stefanescu, p. 159).If in the late $\mathrm{VI}^{\text {th }}$ century the Last Judgment was found both in Byzantine and Western manuscripts, starting from the $\mathrm{XII}^{\text {th }}$ and $\mathrm{XIII}^{\text {th }}$ centuries it was developed in mosaics and on murals (Vătăşianu, 1974, p. 25).

\section{THE LAST JUDGMENT IN VORONET AND THE SISTINE CHAPEL}

In Voroneţ, founded by Stephen the Great, the exterior painting, where the Last Judgment also appears, was createddue to the care of the Moldavian Metropolitan Grigorie Rosşca, by a painter named Prístav Mark, in 1547 (Oprescu, 2007, p.112). 


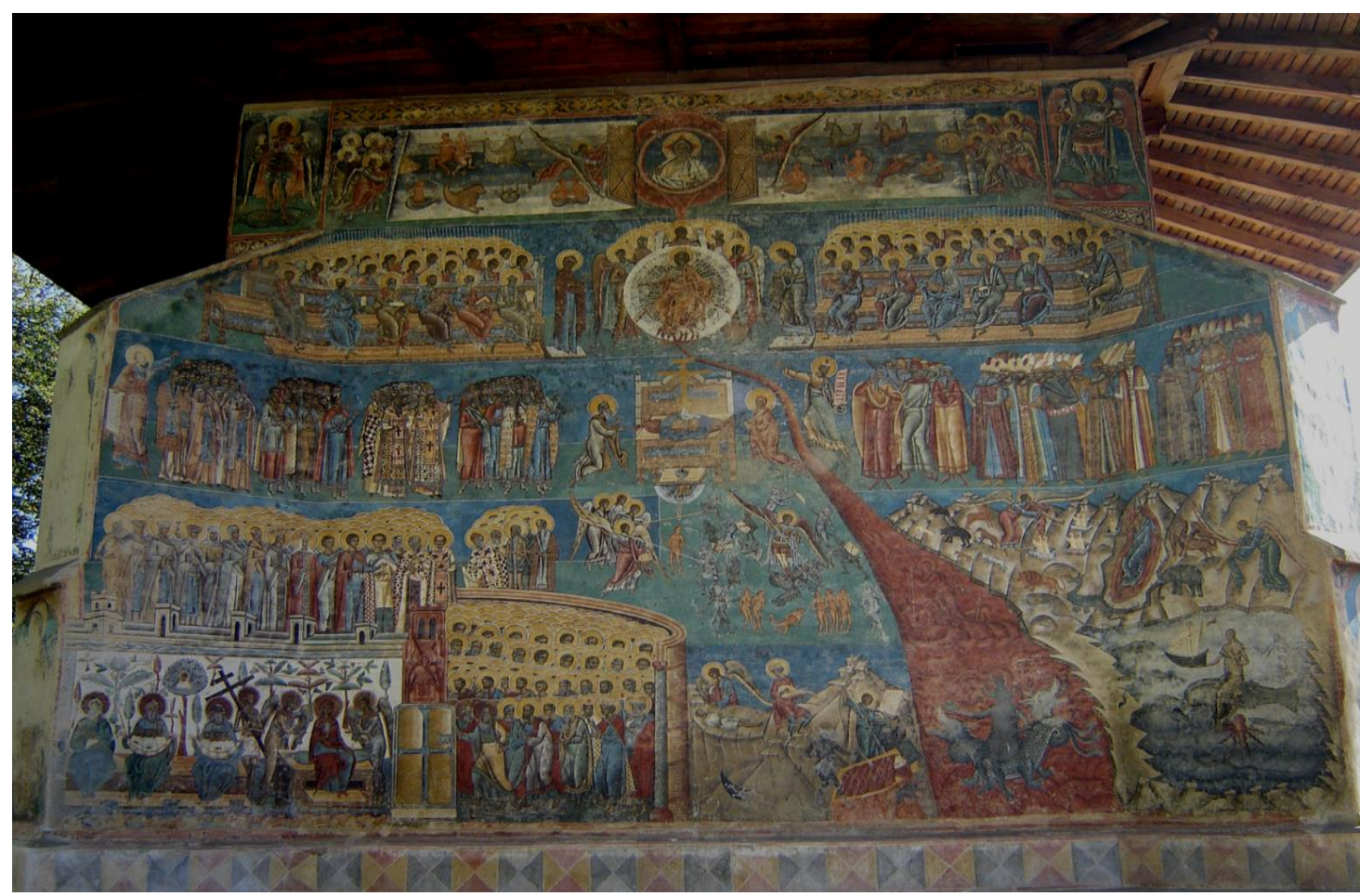

Fig. 1 The Last Judgment. Voronet

The scene follows to a great extent Byzantine iconography. The composition is clear, the groups of characters are organized, individualized, one being able to easily see each register separately. Everything is rendered on a blue background which, over time, has given rise to the name of Voronet blue. It attracts the specialists' attention due to its resistance to quite tough climatic conditions, which demonstrates a particular artistic technique employed by the artists of the time (please see Istudor, 2009, pp. 211-229).

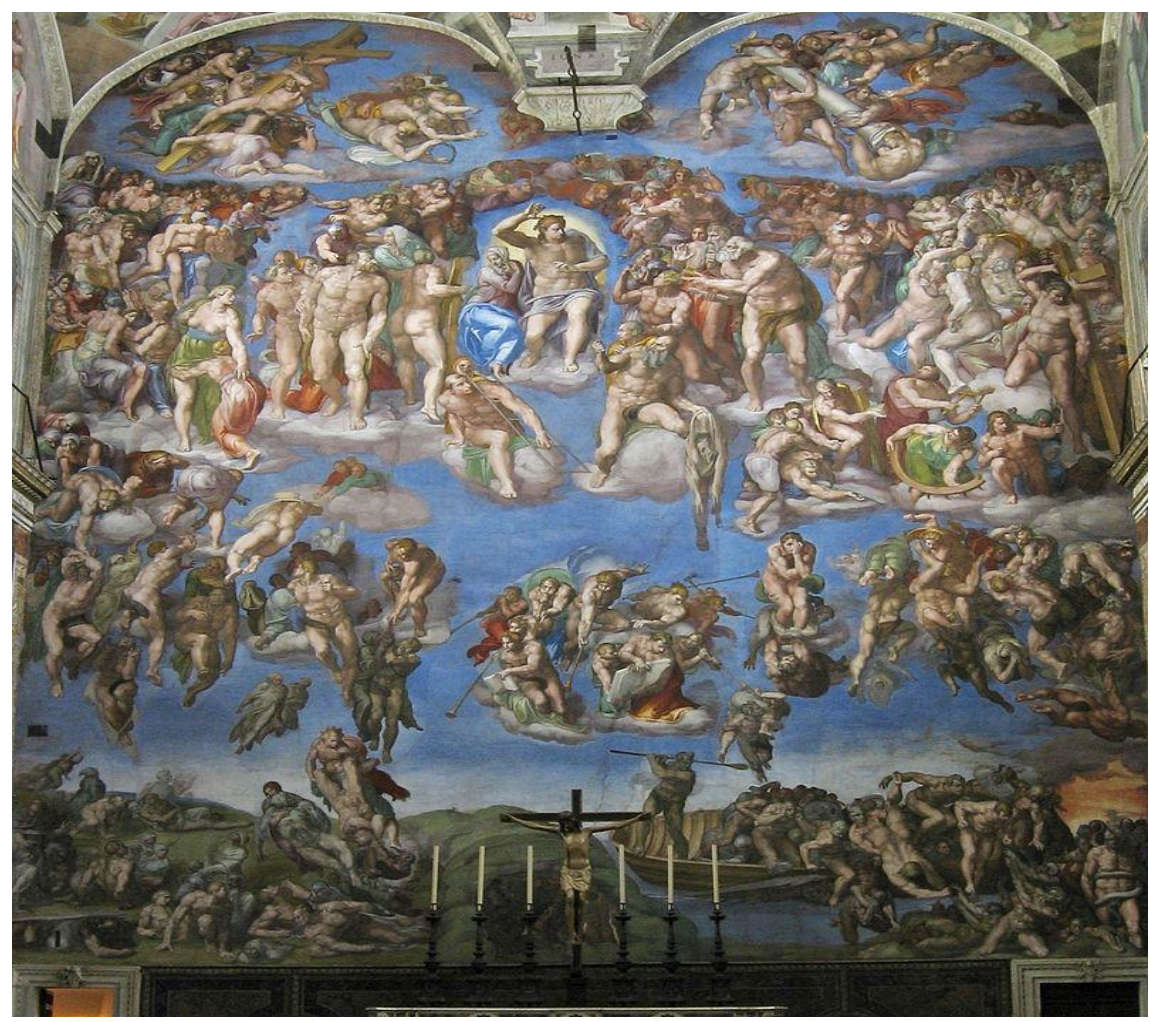

Fig. 2 The Last Judgment. The Sistine Chapel. Michelangelo.

https://upload. wikimedia.org. 
In the Sistine Chapel, on the altar wall, six years before the Moldavian work, Michelangelo gave birth to a monumental, open and dynamic (Fig. 2) composition, one with a great dramatic load. Just like in the case of the Moldavian work, Michelangelo's work was also painted on a blue background. The Italian artist's work is not organized as that of Voronet, in several registers, but it creates the impression of a vortex which starts from the raised hand of Christ.

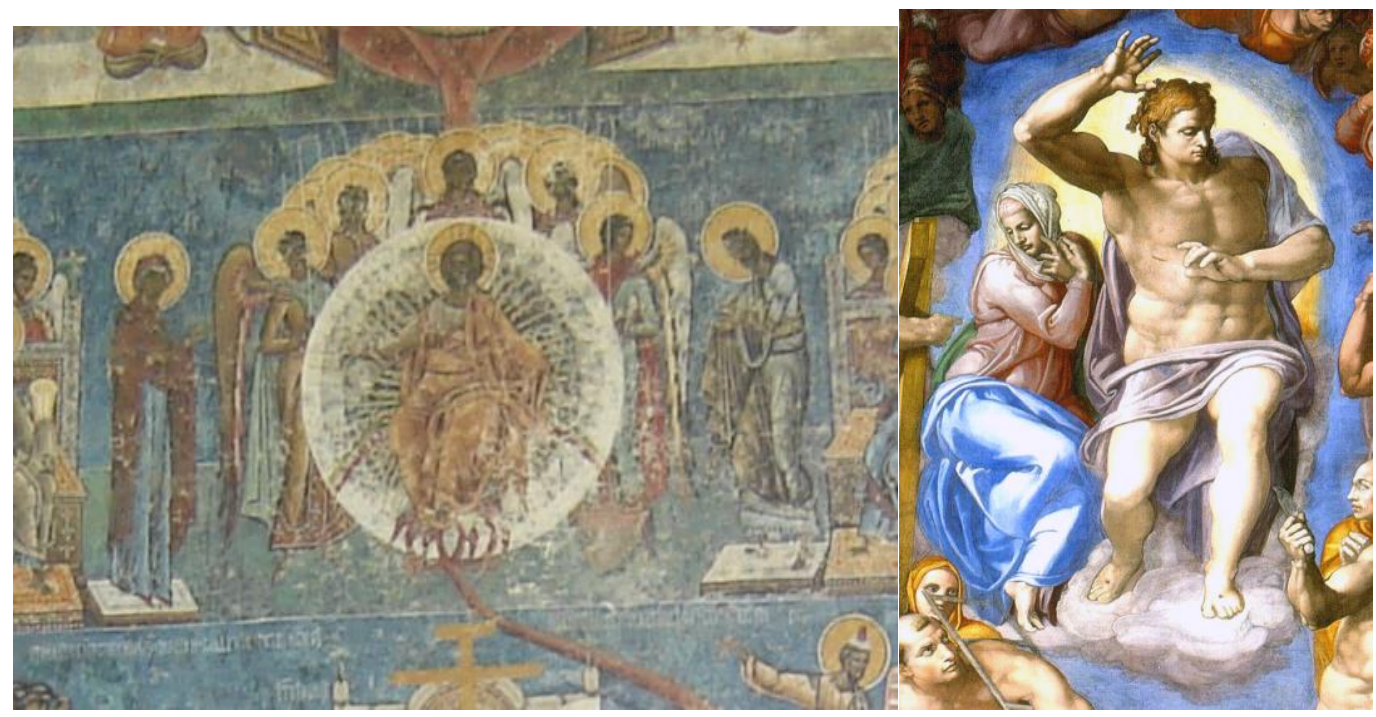

Fig. 3 Deisis. Voronet. Detail

Fig. 4 Detail. The Sistine Chapel

In both works the central figure is that of the Saviour. At Voroneţ, Christ appears on a chair, framed by cohorts of angels, by apostles, and to His left and right sides, by Virgin Mary and John the Baptist, forming the Deisis (Fig. 3). Michelangelo renders Christ's body naked, after the model of the Antiquity, scantily covered by a garment, with the right hand raised, sitting on a cloud, announcing the Baroque. With his other hand he calls the believers (Fig. 3). "The adolescent beardless face, like that of Apollo, is facing the damned. But His eyes look down. His countenance shows no anger, but rather self-control. The outline of his stature is calm, overlapping the aureole where from it seems to come out, but which still retains it. Seen purely frontal, Christ is the centre of all movement around Him" (von Einem, 1984, p. 171).Virgin Mary from the Sistine Chapel appears with her body close to the body of Christ, but does not regard Him the way Virgin Mary from Voronet does. She beholds those from the bottom, with fear of her Son's action. Her gesture is one of sympathy, as if trying by attitude and facial expressions to warn about what is going to happen (Von Einem, p. 171).Virgin Mary and John the Baptist attempt to improve the action of Christ in the Sistine Chapel. The folds of the garments follow the shape of the body, whilst, at Voronet, this naturalness is absent and garments are rendered in a geometrical fashion in compliance with Byzantine iconography. Virgin Mary and John the Baptist are rendered standing, with their heads slightly bowed in a gesture of prayer.

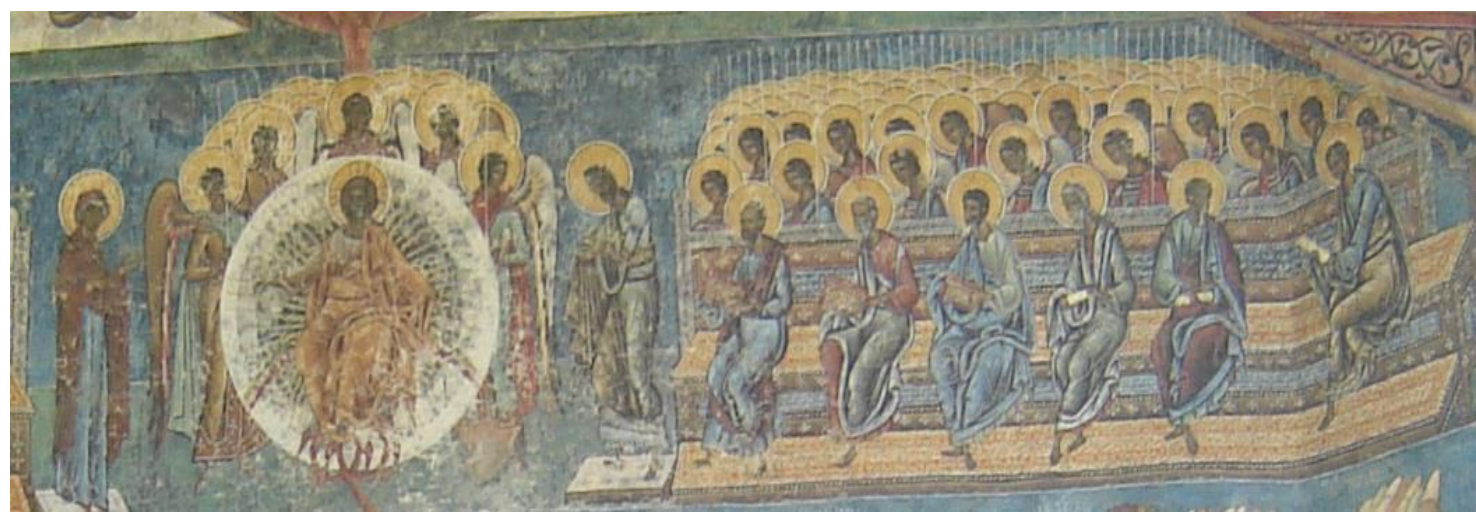

Fig. 5 Voronet. The Apostle, the Register from the Right. Detail

At Voronet, Jesus, as a judge, appears surrounded by the cohort of angels, and with the apostles on both his sides, sitting on benches, decorated with traditional Romanian motifs, as representatives in the Judgment court (Fig. 5) (Vătăşianu 1974, p. 27). The motifs are part of the local elements introduced in this sceneas 
compared to the Byzantine iconographic tradition.

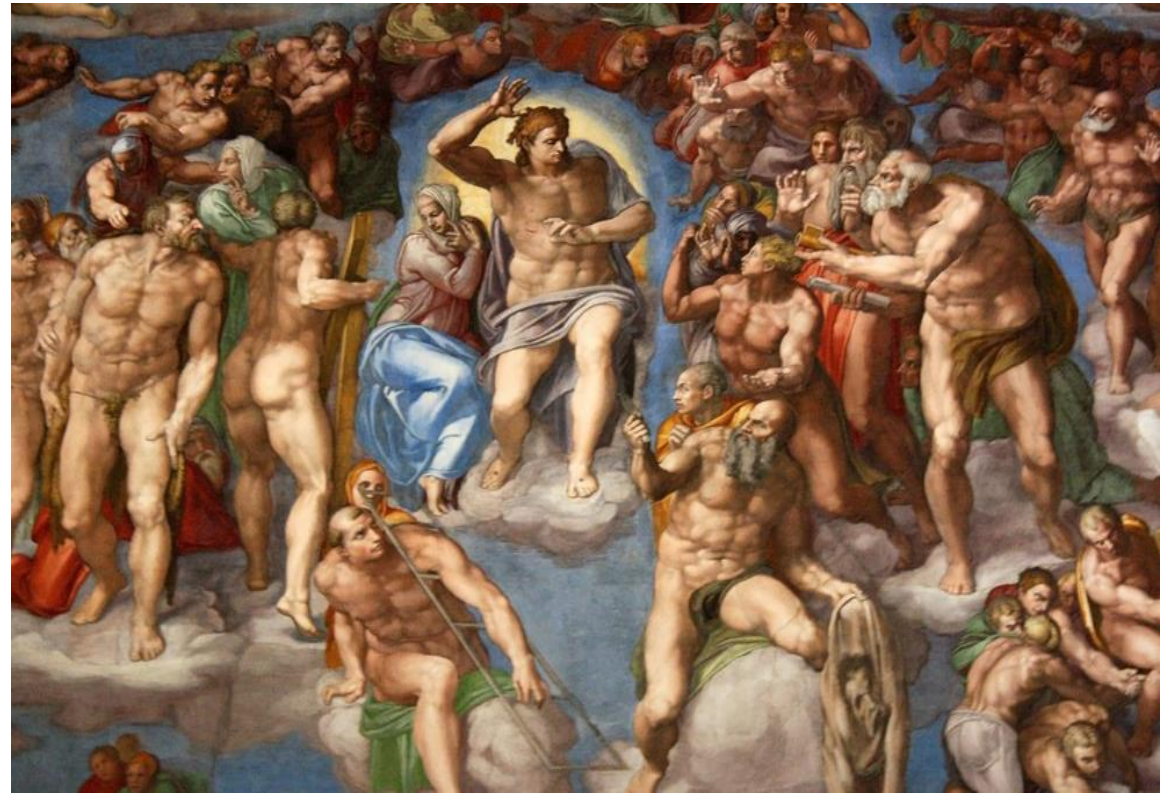

Fig. 6 Detail.The Sistine Chapel

Around Christ, the Italian painter represents, in a dramatic manner: Adam, St. Peter, the apostles, the prophets. Thus, some of them appear with the tools that led to their peril. For example, Bartholomew holds the knife in the right hand and in the other hand he holdshis skin, because he was flayed alive. On the skin, the Italian artist painted his self-portrait (Fig. 6) (Vătăşianu, 1972, p. 120). Next is the countenance of St. Lawrence. The sinners the condemned collapse to hell, but not through the lake of fire, as we see at Voronet. In the upper right, at the bottom, there is a representation of Charon with the boat from which he shovels down those who will descend into Hell (Vătăşianu 1972, p. 120). The idea was taken from the work of Dante (Vasari, 1968, p. 220).

The bold foreshortenings, the articulated bodies floating in the void highlight the tragic character of the work. He painted those whose sins had been forgiven hugging one another with joy. Some help others rise by stretching their hand. It is remarkable how the Italian artist succeeded in expressing fear on the faces of sinners, but also sin, taking into account every detail related to: attitude, appearance or gestures of the characters. The manner of representation may be considered a warning against the way everyone lives by forewarning the people that judgment day will come for everyone. Most researchers have established a link between the modality of the work design by the Italian artist and the events he had encountered throughout his life, namely the life and death of Savonarola and the religious Reformation that both put their imprint on his work.

Regarding the sources of inspiration, if at Voronet a number of local elements are added to the specific Byzantine character, at Michelangelo one may find influences coming both from the eastern painting, starting with Torcello, to which other monuments in the area add up, and from the north-western and western one (Von Einem, pp. 178-184).

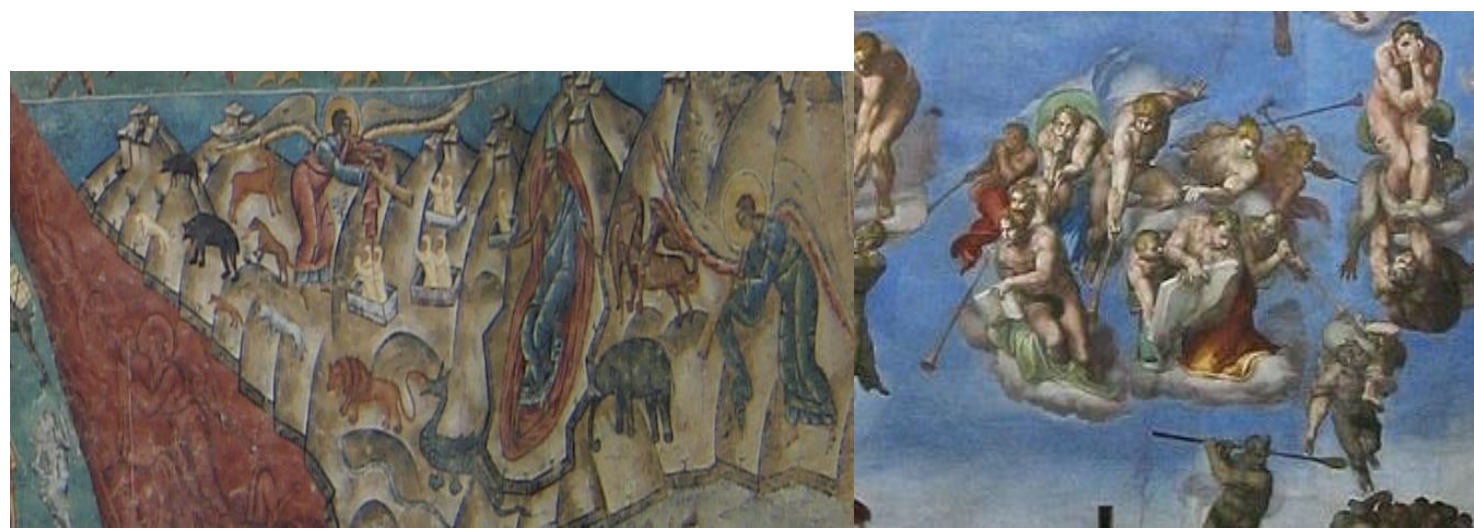

Fig. 7 Resurrection. Voronet. Detail

Fig. 8 Resurrection. The Sistine Chapel. Detail 
Figures 7 and 8 show details of the resurrection of the dead from the two scenes of the Last Judgment. In Fig. 7, Archangels Michael and Gabriel sound the horn to wake the dead from eternal sleep. When hearing the sound, these rise in the form of white mummies. The tombs are opened by the earth, allegorically rendered through a man with a high fur hat on his head. The resurrection of people eaten by animals is exposed through wild beasts who blurt out their limbs from their mouths (Vătăşianu 1974, p. 27).

Below, the allegory of the sea is highlighted, expressed by a woman sitting on a dolphin with a ship in her hand. Around her, birds and fish release the dead (Fig. 9) (Vătăşianu, 1974, p. 27). In the Sistine Chapel, the time is announced by a group of angels who seem as if floating on clouds, blowing down the trumpets to make themselves heard by the dead. Two angels hold a book in their hands as a symbol of awareness of their sins. Their faces express fear, horror, the eyes are bulging, trying to frighten those who watch them, and the positions of the agitated, twisted bodies deepen the dramatic nature that characterizes the whole composition.

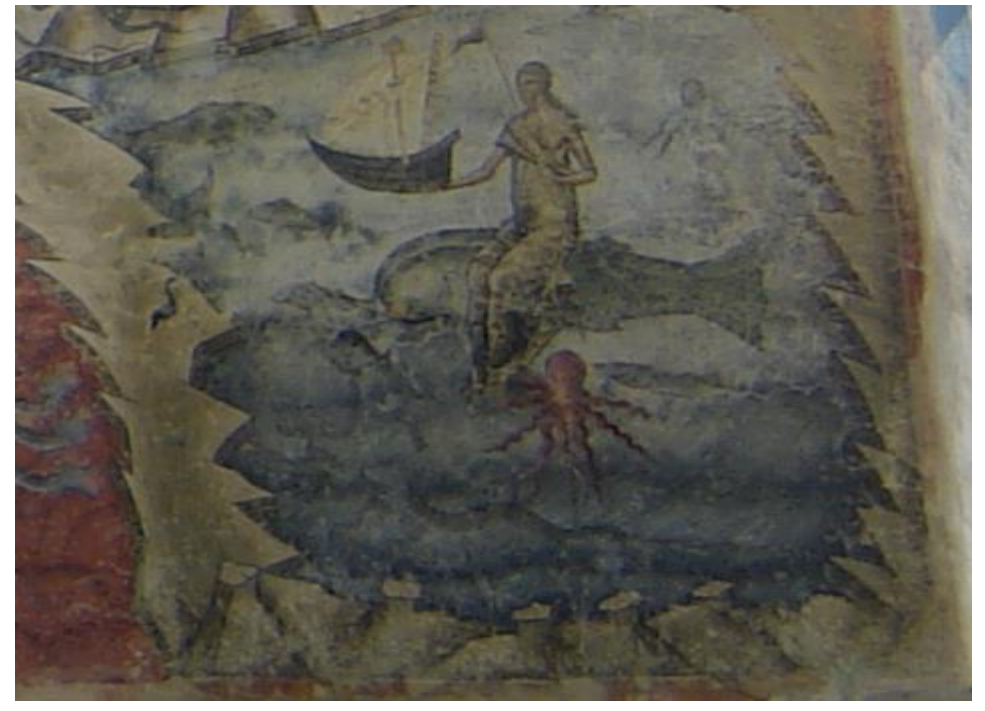

Fig. 9 The Allegory of the Sea. Voronet. Detail.

There are several elements missing from Michelangelo's Judgment that, nonetheless, can be found at Voronet, such as the Hetoimasia Throne (Fig. 10): pigeon, gospel, cross, nails, framed by Adam and Eve kneeling down; the river of fire that springs from Christ's feet and flows to the right corner of the composition, in which the sinners eaten by the dragon that awaits them below hurtle down (Fig. 11), and under the Hetoimasia Throne there hangs the scales of justice (Fig. 12).

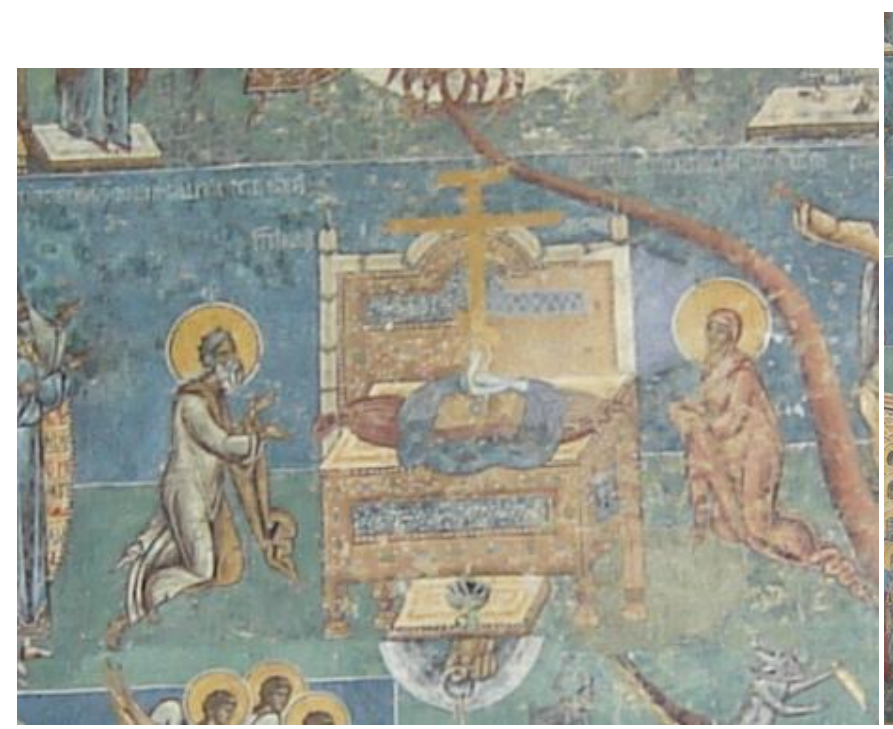

Fig. 10 The Hetoimasia Throne. Detail

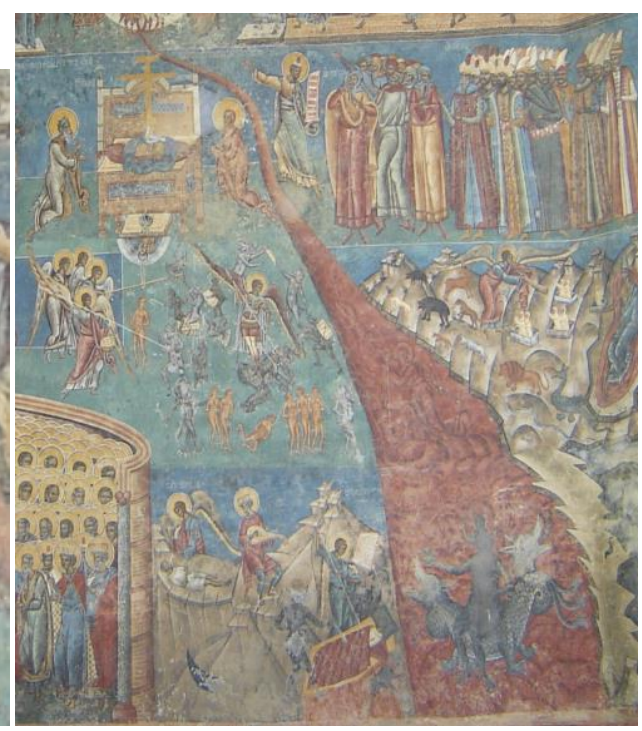

Fig. 11 The River of Fire. Detail 


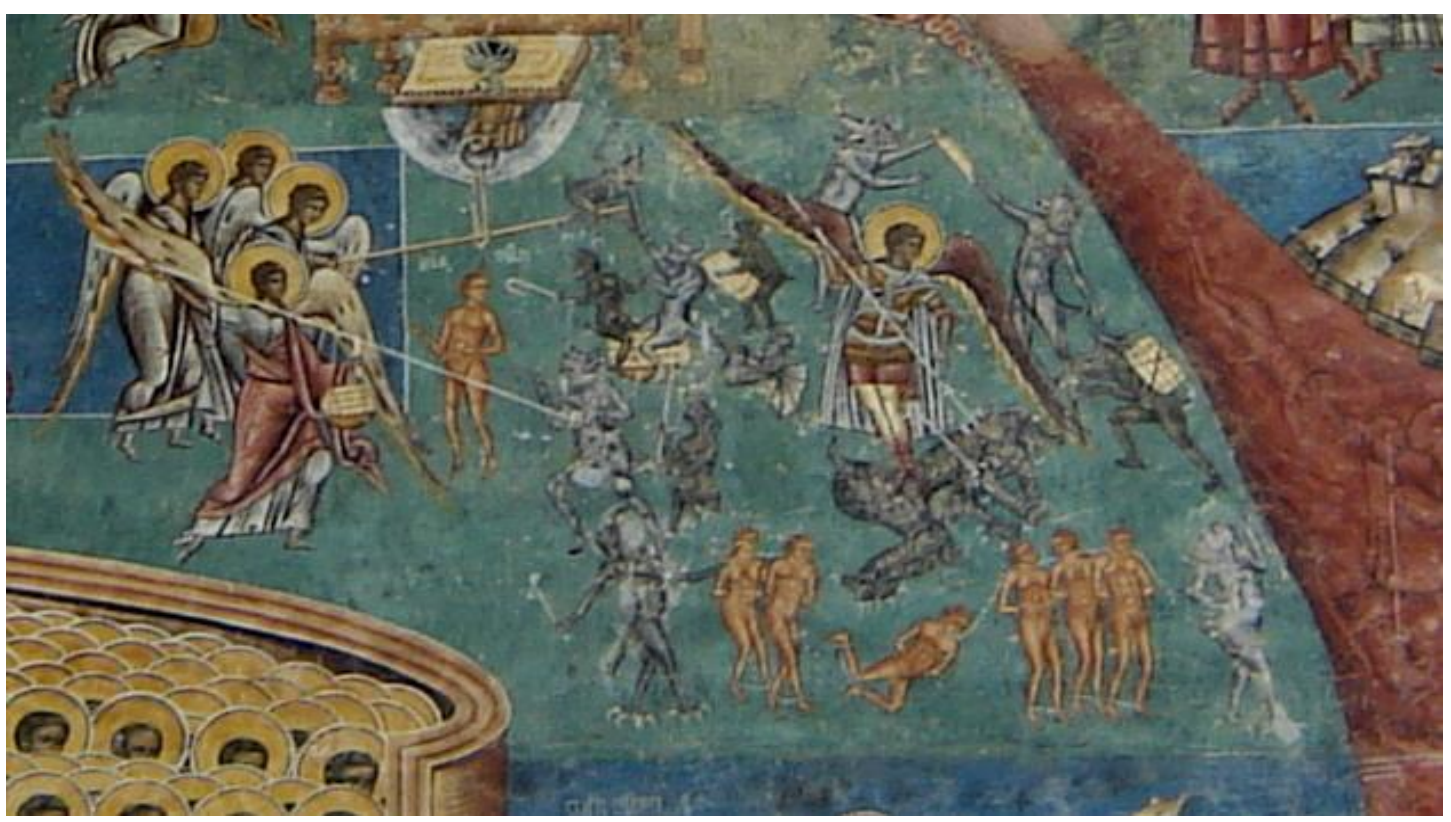

Fig. 12 The Scales of Justice. Detail

It is presented in the form of a hand, believed to be God's hand, holding the scales to weigh the sins. The angels, led by the Archangel Michael, cast out the demons that pull the hook to balance it in their favour, so as to steal as many souls as possible. The naked bodies of the sinners are led in chains to hell, to be tormented in the river of fire from the right (Vătăşianu 1974, p. 27). There awaits the dragon that swallows Judas, Christ's betrayer.

To the left of the Hetoimasia Throne the groups of believers are presented, while in the register from the right one can see the figure of Moses with the tablets of the law in his hand. He rebukes unbelievers among which are included: the Hebrew, the Tatars, the Turks and the Armenians (Fig. 13). Their presence is different from that in the Byzantine Erminia. On the one hand, this was a warning as regards the reform that had been introduced in Transylvania since there any heresy could weaken the church, with which the state had a very strong bond (Florea, p. 169). And, on the other hand, the introduction of this new element in the scene is considered by the Romanian art historian Vasile Drăguț "an iconographic invention specific to old Romanian painting". It thus underlines the desire for freedom shown at the time by the Romanian people and it is a call to defend the country (Nice, 2000, p. 223). This is a way to break loose from the foreign occupation by invoking divinity (Musicescu, Ulea, 1971, p. 14).

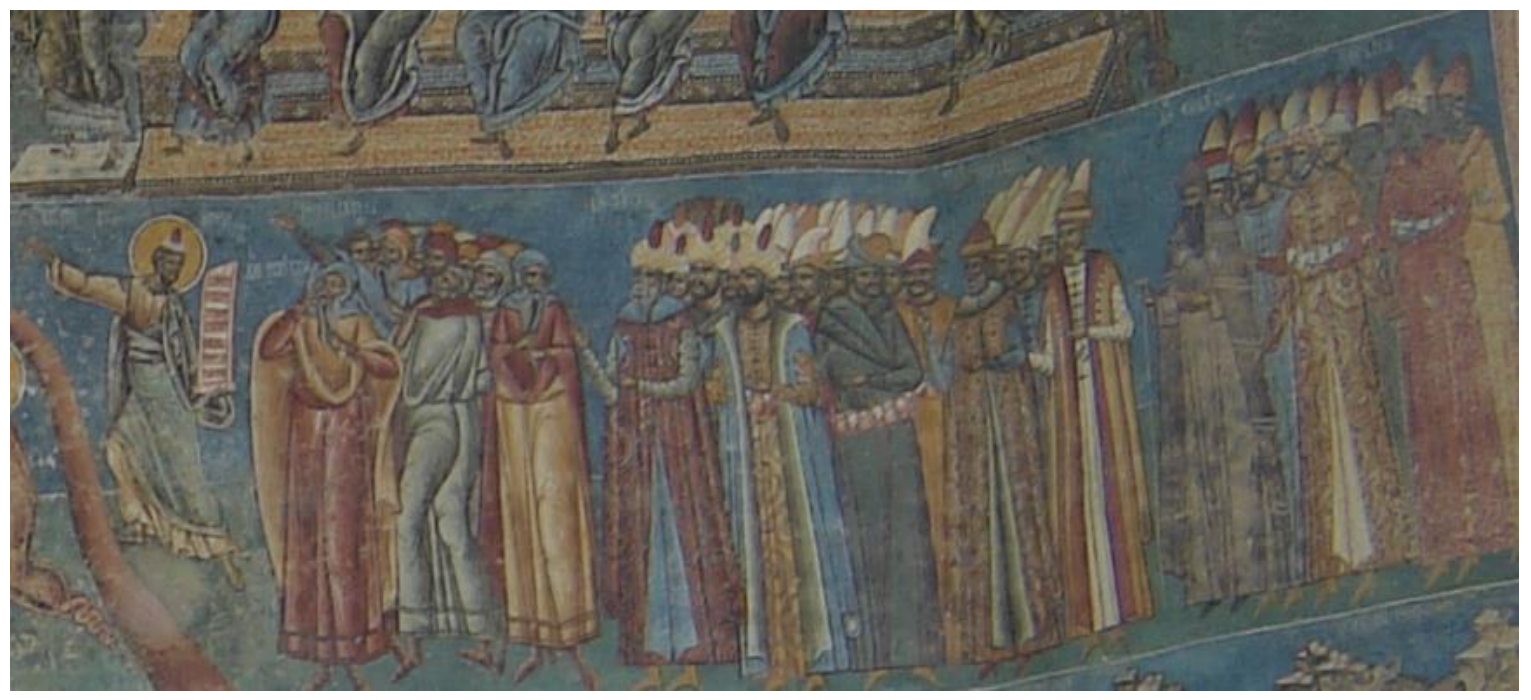

Fig. 13 Groups of Hebrew, Turks, Tatars and Armenians. Detail

In the register from the left appears the group of the saved ones, led by the apostle Paul. (Fig. 14) They turn to the gate of heaven where St. Peter is waiting with the key in his hand. 


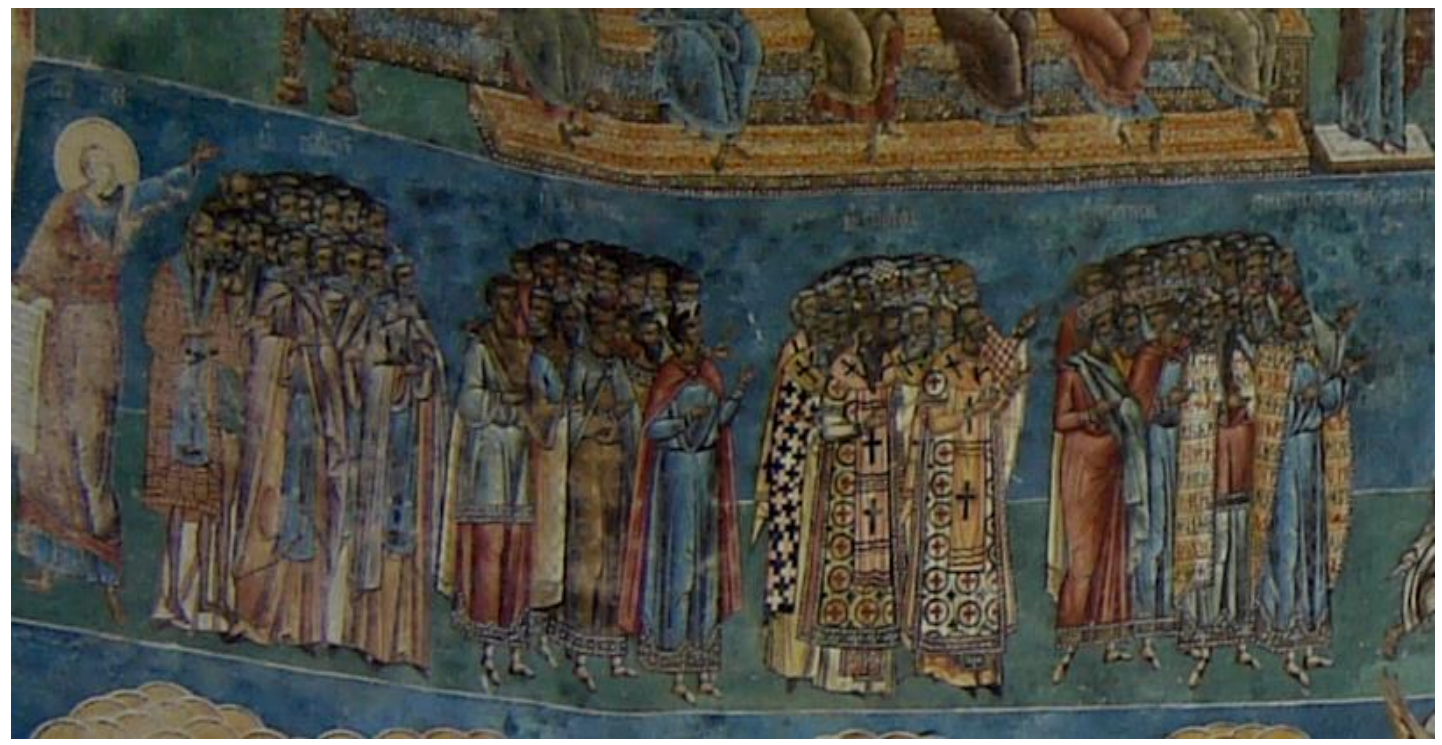

Fig. 14 The Groups of the Redeemed. Detail

Behind the gate is painted heaven, where one may notice, on a white background, specific to its representation, amidst the vegetation, Mary's face with two angels on her sides. Along comes the good thief who carries his cross, then the patriarchs Abraham, Isaac and Jacob, holding the souls of the redeemed in their lap, in traditional towels (Fig. 15) (Vătăşianu, 1974, p. 27).Among the vegetation there appears a fruit tree, the Tree of Life, in the middle of whose crown the image of Christ is highlighted. In relation to the Erminia, here the virgins groups are not present.

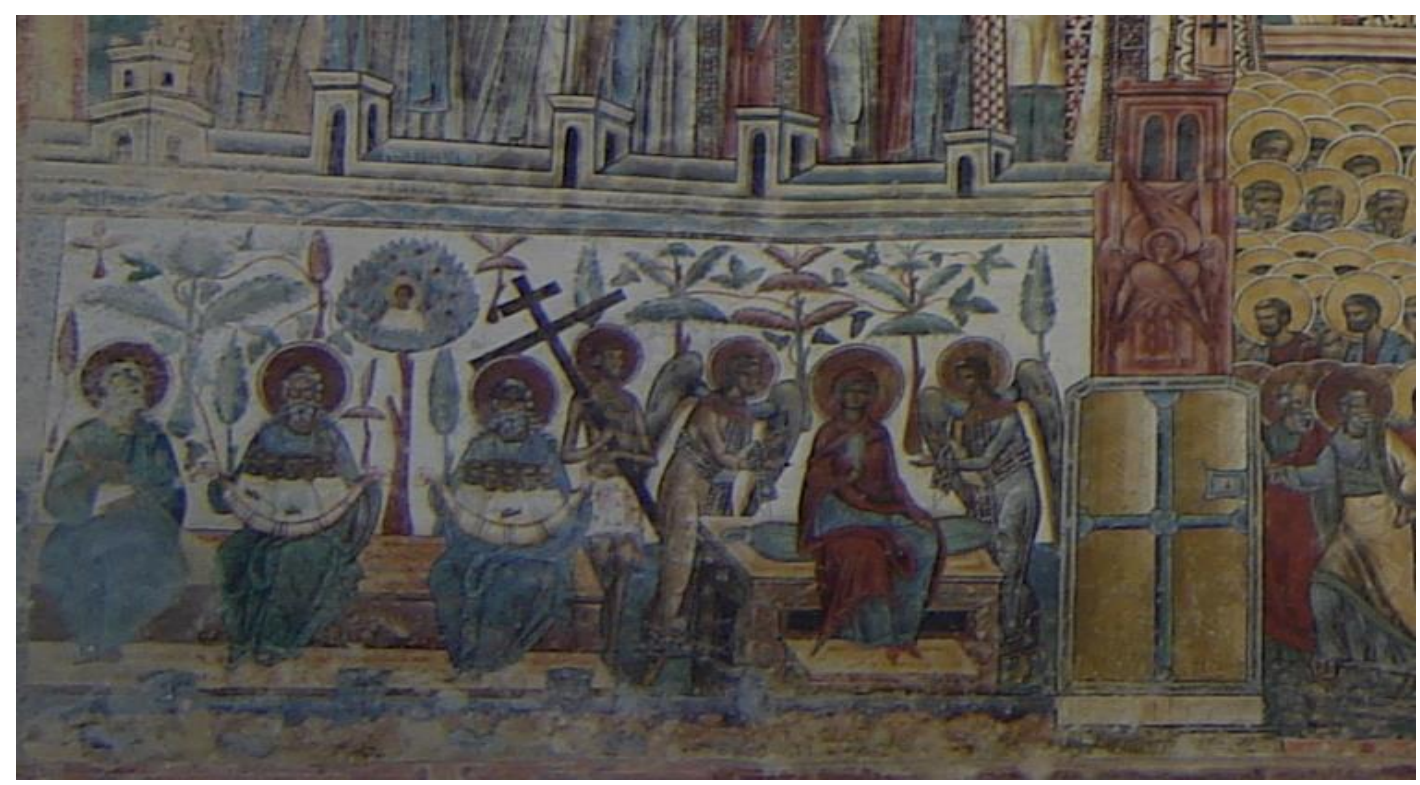

Fig. 15 Gate of Heaven and Heaven. Detail

At the bottom, in the last register, between the river of fire and the group of the righteous that are close to the gate of heaven the scene is completed by the image of David sitting on the rocks playing the kobza. On each side one can observe the death of the believer and the death of the sinner (Fig. 16). The guardian angel takes the soul of the former in due time, while the latter dies in torment. 


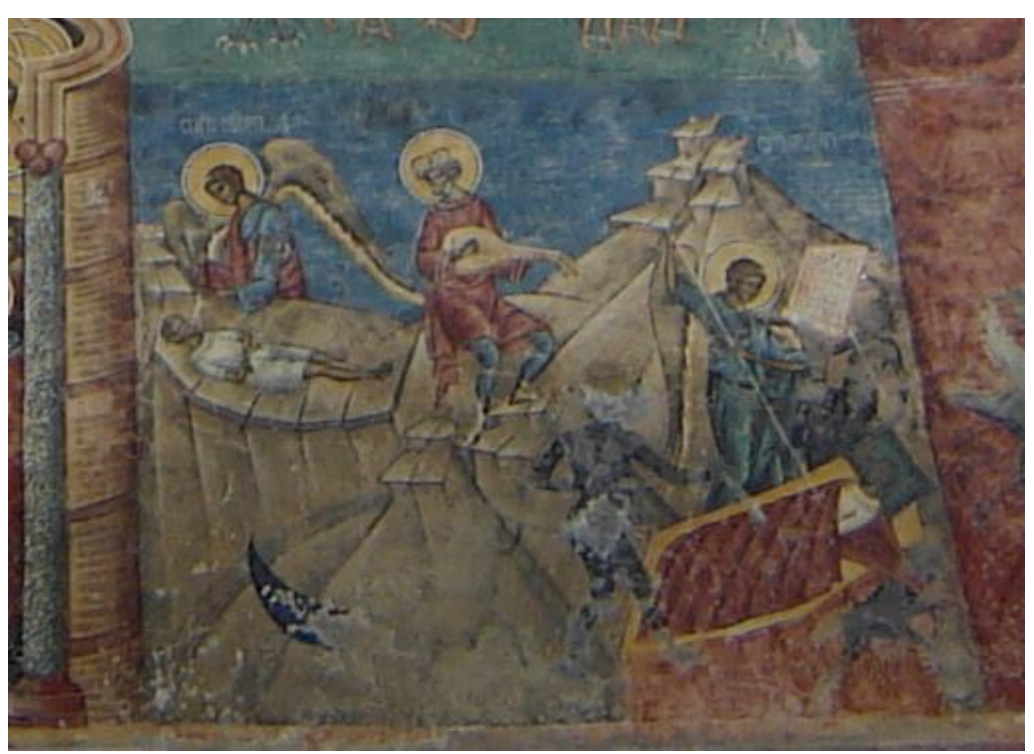

Fig. 16 Death of the Poor and Death of the Rich. Detail

In the Sistine Chapel, Michelangelo introduced contemporary characters, such as Biagio da Cesena. Georgio Vasari mentions the moment when the Pope asked for his opinion about the scene that was going to be ready shortly. The master of ceremonies replied unfavourably, cataloguing the painting as "more than wanton, placed in a so noble spot and that it was not suited to the chapel of the Pope, but to a bathroom or an inn" because of the nudes. In order to avenge on him, the painter introduced him in the work, in the upper, down corner, in hell, in the guise of Minos, rendering him naked with a snake around his foot and with many demons around him (Vasari, p. 217, vol. 3).

In the upper register the two representations of the Last Judgment have different scenes painted. At Voronet one can see God the Father, and on both sides the 12 zodiac signs, then groups of angels by four and the Archangels Michael and Gabriel (See fig. 17).Looking from the top to the bottom, starting from God the Father from the upper register, the Trinity can be observed: God the Father, Jesus Christ, His Son and the Holy Spirit, symbolized by the dove. Michelangelo painted in the two scopes the angels bringing the tools of Christ's sacrifice, proving the guilt of mankind(Fig. 18) (Vătăşianu, 1972, p. 120).Sitting on clouds, with their bodies contorted, twisted, some of them floating in the void, they hardly manage to hold the cross and the pillar.

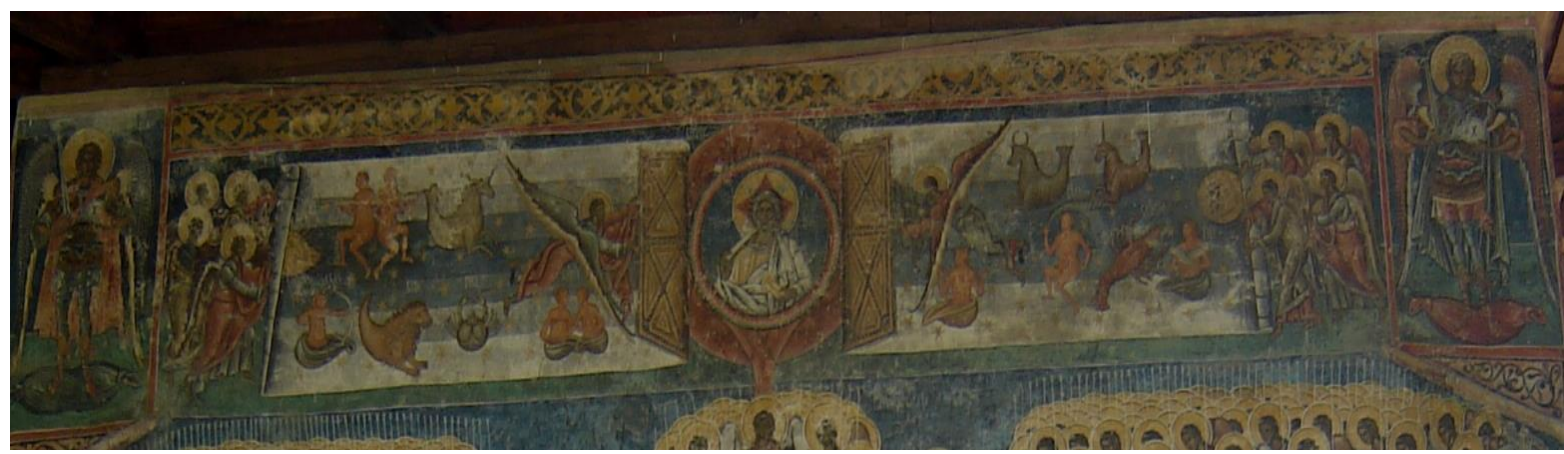

Fig. 17 Voronet.Upper Register. Detail

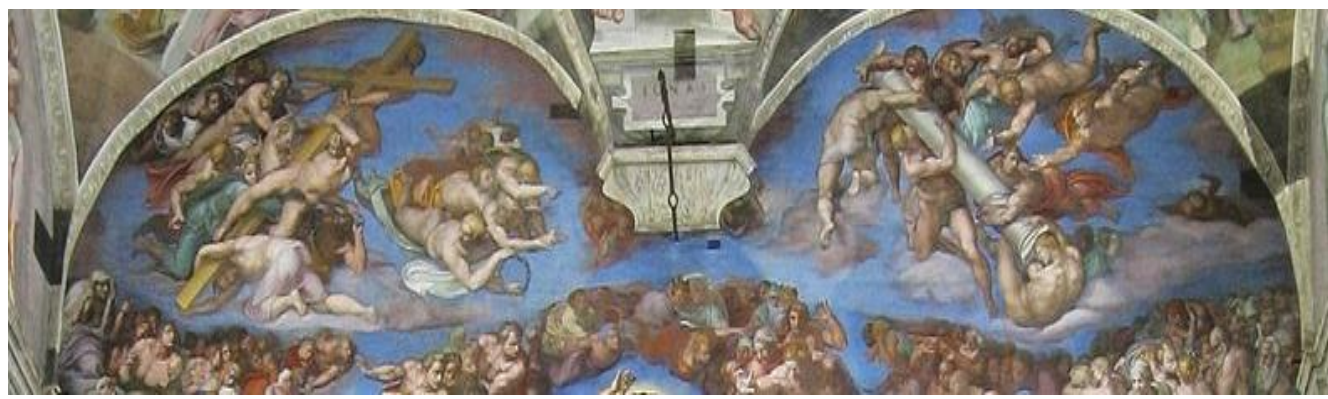

Fig. 18 The Sistine Chapel. Upper Register. Detail 


\section{CONCLUSIONS}

With regard to the large composition painted by the Italian artist, Andrei Otetea states that: "Michelangelo united the pagan sense of physical beauty with the pathetic nature of the Christian religion that divinizes suffering" (Otetea, 1941, p. 296).

He created an open composition exiting the usual patterns, which gives the impression that it is not over, that it continues beyond its boundaries. Apart from daring to render with so much suffering the drama of the contemporary world, he managed to stir up discontent at that time because of the nudes present in a religious composition. He took over the nude from ancient artists, so, to him, "nudity is the natural state of the human being" (Alpatov, 1967 p. 56).Later, some of them would be covered to avoid total destruction of the Judgment. The Italian artist possessed extraordinary knowledge of the anatomy of the human body and its rendering with so much pain, distress and fear made it become one of the most dramatic compositions of this type. He also had thorough knowledge about design, focusing on every detail, the technique of muscles painting being inspired by Greek sculptors (Gombrich, 2012, p. 310) The contorted, twisted, agitated characters float in the void, move continuously, the righteous rise to heaven while the wicked crash down in agony to hell.

At Voronet, the Byzantine iconography tradition was almost entirely respected; to it, some new elements were added that gave the work originality, such as the groups of strangers or traditional objects such as: the bench, the kobza, traditional towels etc. One may find here the contrast between the serenity of the angels and the faces of the demons, as well as tranquillity, quiet grace, realism of the faces, etc. The painting of Moldavian churches is described in the following manner:"In no other country in Europe, not even in the birth land of the mural painting in Italy, will we find anything remotely similar to these churches whose harmonious colours sparkle on the green of the clearings, on the trembling background of the hills of beautiful Moldavia" (Historical Monuments ..., 1974). The composition is clear, symmetrical tragic sense is not rendered with the same force of suggestion as in Michelangelo's work, but the warning as regards the way in which each human being leads its life is highlighted with refinement.

\section{REFERENCE LIST}

Mihail Alpatov, Istoria artei, Meridiane Publishing House, Bucharest, 1967.

Constantin Cavarnos, Ghid de iconografie bizantină, Sopia Publishing House, Bucharest, 2005.

Dionisie din Furna, Erminia picturii bizantine, Sopia Publishing House, Bucharest, 2000.

Vasile Drăguţ, Arta românească, Vremea Publishing House, Bucharest, 2000.

Vasile Drăguţ, Dicţionar de artă medieval românească, The Scintific and Ecyclopedic Publishing House, Bucharest, 1976.

Herbert von Einem, Michelangelo, Meridiane Publishing House, Bucharest, 1984.

Vasile Florea, Istroia artei româneşti, Litera-Internaţ̧ional Publishing House, Bucharest-Chişinău, 2007.

E.H.Gombrich, Istoria artei, Art Publishing House, Bucharest, 2012.

Istudor I., Biserica Mânăstirii Voroneţ, Retrospectivă asupra cercetărilor privind materialele şi tehnica picturilor murale, Archbishop of Suceava and Radauti, Voronet Monastery, in the volume „Sfânta Mănăstire Voroneţ, 520 de ani”, Muşatinii Publishing House, Suceava, 2009.

Victor Lazarev, Istoria picturii bizantine, vol I, Meridiane Publishing House, Bucharest, 1980.

Maria Ana Musicescu, Sorin Ulea, Voroneţ, Meridiane Publishing House, Bucharest, 1971.

Carmen Oprescu, Arta feudală pe teritoriile româneşti. Scurtă istorie ilustrată, Ars Docendi Publishing House, Bucharest, 2007.

Andrei Oţetea, Renaşterea şi reforma, Royal Foundation Publisher for Literature and Art, Bucharest, 1941.

Constantin Suter, Istoria artelor plastice, Didactic and Pedagogical Publishing House, Bucharest, 1967.

I.D. Ştefănescu, Iconografia artei bizantine şi a picturii feudale româneşti, Meridiane Publishing House,1973. 
IJASOS- International E-Journal of Advances in Social Sciences, Vol. III, Issue 9, December 2017

Giorgio Vasari, Vieţile pictorilor, sculptorilor şi arhitecţilor, Meridiane Publishing House, Bucharest, 1968. Virgil Vătăşianu, Pictura murală din nordul Moldovei, Meridiane Publishing House, Bucharest, 1974.

Virgil Vătăşianu, Istoria artei europene, Meridiane Publishing House, Bucharest, 1972.

Monumente istorice bisericeşti din Mitropolia Moldovei şi Sucevei, laşi, 1974. 